\title{
REFLEKSIE EWANGELICZNE
}

Felicja Zuurowska, Kraków

\section{LASKA OSTATNIE』 GODZINY \\ (Material do pogadanki ewangelicznej)}

\section{TEKST EWANGELIL ${ }^{1}$ )}

I przyszli na miejsce, które się nazywa Kalwaria, a po hebrajsku Golgota, to jest miejsce Trupiej Głowy... Tam go ukrzyżowali, a z nim dwóch łotrów, jednego po prawej, a drugiego po lewej stronie, pośrodku zaś Jezusa. I wypełniło się Pismo, które mówi: „I do złoczvńców zaliczony był".

A jeden z powieszonych łotrów bluźnił mu, mówiąc:

- Jeśliś ty jest Chrystus, wybawże samego siebie i nas.

A jeden z powieszonych łotrów bluźnił mu, mówiąc:

- Ani ty Boga się nie boisz, choć tę samą ponosisz karę. My co prawda sprawiedliwie, słuszną bowiem zapłatę za uczynki odbieramy, ten wszakże nic złego nie uczynił.

I mówił do Jezusa:

- Panie, wspomnij na mnie, gdy przybędziesz do królestwa twego. -

I rzekł mu Jezus:

- Zaprawdę powiadam tobie, dziś ze mną będziesz w raju. -

\section{ANALIZA TEKSTU}

\section{Typ tekstu}

Opis zdarzenia historycznego.

\section{Temat}

Nawrócenie dobrego łotra.

1) Tekst niniejszy podany jest wediug ks. Eugeniusza D a b ro wskiego, Zycie Jezusa Chrystusa - w opisie ewangelistów, Pallotinum, Poznań 1957, s. 392 i 396. 


\section{Tekst}

Mt 27, 38, 44;

Mk 5, 27-28, 32;

Ek 23, 33, 39-43;

Jn 19, 18.

Spośród trzech synoptyków jeden tylko Marek przypomina słowa Pisma św., czego nie ma zresztą $w$ zwyczaju $w$ innych miejscach swej ewangelii to jeszcze nie byłoby, ostatecznie, nic nadzwyczajnego, ale ponieważ tekstu tego brak w bardzo starych i poważnych edycjach Pisma św., więc niektórzy bibliści uważają to zdanie za interpolację jakiegoś kopisty. Inni jednak egzegeci sądzą, że jest ono autentyczne. Są oni jednak w mniejszości, toteż większość wycań Pisma św. wiersz ten (28) pomija, choć pod względem rzeczowym nie można mu oczywiście nic zarzucić. $\left.{ }^{2}\right)$

\section{Czas zdarzenia}

Wielki Piątek, 7/4 30 r. (14 Nizan). Dzień śmierci Pana Jezusa.

\section{Miejsce zdarzenia}

Góra Kalwaria pod Jerozolimą.

\section{Uczestnicy zdarzenia}

Pan Jezus i dwaj łotrzy, wiszący po prawicy i lewicy Chrystusa.

Kim byli owi dwaj łotrzy nie zostało ustalone z całkowitą pewnością. Nie znane też są przestępstwa, za które zasłużyli na karę śmierci. Św. Mateusz i św. Marek zowią ich zbójami, pod którym to mianem rozumie się zwykle tych, którzy łupią innych z bronią w ręku. Sw. Eukasz wyraża się bardziej oględnie, zowiąc ich przestępcami. W Wulgacie powiedziano o nich ,,złodzieje“. ${ }^{3}$ ) Prawo żydowskie zabraniało wykonywania wyroku śmierci na dwóch osobach jednego dnia. Ale Rzymianie mało sobie $\mathrm{z}$ tego robili i stosowali równocześnie nawet masowe egzekucje ${ }^{4}$ ). Nie wiadomo dlaczego właśnie ci dwaj ludzie zostali ukrzyżowani równocześnie z Chrystusem. Jedni bibliści przypuszczają, że Piłat chciał $\mathrm{w}$ ten sposób uczynić na złość Żydom, dając Chrystusowi - którego napis na krzyżu nazywał oficjalnie królem żydowskim, zresztą wbrew woli Żydów - za współtowarzyszów kaźni dwóch, zwykłych opryszków. Inni znów egzegeci przypuszczają wręcz przeciwnie, że stało się to z woli Żydów, którzy chcieli w ten sposób upokorzyć i wydrwić Chrystusa, równając go ze zbrodniarzami. Jeszcze inna hipoteza -

2) Według L. P ir ot: Evangile selon St. Marc, Paris 1935, s. 395.

:) J. W.

$\left.{ }^{4}\right)$ O. Denis Buzy SCJ: Evangile selon St. Mathieu, Paris 1935, s. 373 . 
może najbardziej prawdopodobna - kładzie ten fakt po prostu na karb przypadkowego zbiegu okoliczności, spowodowanego koniecznością wykonania terminowych wyroków przed Paschą. Tak czy owak spełniło się dzięki temu proroctwo Izajasza: „I do złoczyńców zaliczony byt!" ${ }^{5}$ ).

Jeżeli chodzi o imiona dwóch łotrów to różne dzieła podają różne ich odmiany. I tak dla dobrego łotra wymieniane są następujące imiona: Dy smas (Dismas), Z o a th a m (Zoatan), J o a t a S, T ytus i Mo a b. Dla złego lotra: Gest as (Geglas, Gistas, Gesmas), $\mathrm{C}$ a m m a (Chammata), M a g a tras, D u m a chus (Dimachus) i Z a ndrun (Zandim) ${ }^{6}$ ). W polskiej tradycji kościelnej utarło się nazywać dobrego łotra: D y z ma, a złego: Kosma.

Apokryfy nie omieszkały oprząść ich dziejów wątkiem legendy. Oto co referuje na ten temat ks. Józef $\mathrm{K} \mathrm{a} \mathrm{c} \mathrm{z} \mathrm{marcz} \mathrm{y} \mathrm{k:} \mathrm{„Dwa}$ rękopisy "Aktów Piłata» zawierają legendę o spotkaniu się św. Rodziny w czasie ucieczki do Egiptu ze zbójnikiem D y s m a s e m. Ten miał być tak oczarowany pięknością Najśw. Maryi Panny, trzymającej Dziecię w ramionach, iż zawołał: «Gdyby Bóg miał jaką matkę musialby rzec: „Ty nią jesteś!“” Wziął tedy św. Rodzinę do swego domu i polecił trosce swej żony (idąc na polowanie). W czasie jego nieobecności został syn jego uleczony z trądu, skoro tylko go umyto wodą z kąpieli Jezusa. Z wdzięcznością czcił Maryje, wspierał ją na drodze do Egiptu i otrzymał od niej błogosławieństwo." Legenda kończy się słowami: „Dlatego przez łaskę Boga miłosiernego i przyczyne jego matki stał sie godnym poniesienia razem z Chrystusem śmierci męczeńskiej na krzyżu." Nieco w innej formie opowiada o tym spotkaniu Arabska Ewangelia Dzieciatka Jezus: W czasie ucieczki do Egiptu przychodzi św. Rodzina do okolicy niepokojonej przez zbójców. Józef i Maria zauważają, że dwaj zbójcy, Tytus i Dummachus, wypoczywają przy drodze, podczas gdy ich towarzysze śpią w pobliżu. Pierwszy rzecze do drugiego: „Proszę cię, zostaw ich $\mathrm{w}$ spokoju, niech idą, dopóki nasi tego nie zmiarkują!" Gdy się wzbrania Dummachus, obiecuje mu Tytus 40 clrachm i daje mu pas na zastaw. Za to przyrzeka mu Maryja kiedyś odpuszczenie grzechów, a Jezus przepowiada los obydwóch i ułaskawienie Tytusa."7) Oba te fakty są oczywiście bardziej wytworem poetyckiej wyobraźni niż istotnymi zdarzeniami historycznymi i jako takie mają swój swoisty wdzięk.

5) Iz 53,12 i Łk 22, 37.

$\left.{ }^{6}\right) \mathrm{Ks}$. Józef Kaczmarczyk: Meka Jezusa Chrystusa, wedlug czterech ewangelii, Kraków 1932, s. 179. Także, O. Józef H u b y SJ: Evangile selon St. Marc, Paris 1927, s. 423 i inni.

7) Ks. J. K a c zmarczyk d. c. 


\section{Okoliczności zdarzenia}

Zdarzenie to rozegrało się w czasie, gdy Chrystus Pan, skazany na śmierć, wisiał na krzyżu. Podczas tej tragicznej męki nie oszczędzono mu ponadto szyderstw i bluźnierstw. Jak to zwykle bywa przy sensacyjnych zdarzeniach tłum gapiów zbiegł się ze wszystkich stron, głodny wrażeń. Powiada ewangelia, że „lud stał $i$ przypatrywał się" 8 . Wielu zaś przechodziło pobliską drogą, zdążając na paschę do miasta lub odwrotnie do podmiejskich osiedli. Wśród obecnych pod krzyżem nie zabrakło i starszyzny żydowskiej, radców sanhedrynu, przedniejszych kapłanốw i uczonych w Piśmie św. Oczywiście byli i żołnierze rzymscy, którym zlecono wykonanie wyroku. Wszyscy oni, każdy na swój sposób, rzucał obelżywe słowa pod adresem Ukrzyżowanego, apelując do jego - w ich mniemaniu rzekomego bóstwa, mesjaństwa i mocy działania cudów, której powinien był użyć obecnie dla wybawienia się od śmierci. Pan Jezus zniewagi teznosił z godnością, nie odpowiadając na nie ani słowem.

\section{Przebieg zdarzenia}

Nastrój panujący pod krzyżem udzielił się również w sposób sugestywny jednemu z łotrów, ukrzyżowanych wraz z Chrystusem. Co prawda św. Mateusz i św. Marek powiadają, że obaj łotrzy lżyli Chrystusa, ale nie wdają się oni jednak w bliższy opis tej sceny. Można to ich powiedzenie wziąc zatem - zdaniem biblistów - za pluralis gatunku. Dokładny św. Łukasz, który - jak wiadomo - we wielu szczegółach uzupełnił opowiadanie obu tamtych ewangelistów, dzięki ścisłym badaniom, jakim poddał dzieje Chrystusa przed ich spisaniem, szczegół ten rozpracował obszerniej, przekazując potomności scenę o niezrównanym nastroju, tchnącą miłosierdziem, którego był szczególnym piewcą.

Według jego relacji jẹden tylko $\mathrm{z}$ łotrów (tradycja $\mathrm{w}$ tym wypadku wskazuje na łotra, umieszczonego po lewicy Pana Jezusa) począł, za przykładem stojących pod krzyżem, bluźnić Chrystusowi: "Jeśliś ty jest Chrystus wybawże samego siebie i nas!"

Czy wierzył on istotnie $\mathrm{w}$ możliwość tego cudu? Słowa jego. stwierdzają, że nie wierzył $\mathrm{w}$ to, by jego towarzysz kaźni był istotnie Mesjaszem, gdyż dopiero domaga się potwierdzenia tego faktu, cudem uwolnienia. Mógł jednak wiedzieć o tym, że człowiek ten dokonał w życiu swym niejednego dziwu, w każdym razie słyszał, że mu to wytykaja stojący pod krzyżem. Toteż mógł uważać za rzecz pożyteczną zaapelować do tej zdolności, która w chwili obecnej dawała i jemu samemu szansę ratunku z sytuacji bez wyjścia. To,

s) Exk 23, 35 . 
że Chrystus z mocy tej samorzutnie nie skorzystał wydaje się budzić w nim wściekłość, stąd jego wypowiedź - miast pokornej prośby - nosi cechę bluźnierczej prowokacji. W chwili tak dla siebie krytycznej nie zaprząta sobie giowy sprawa swej pośmiertnej przyszłości, myśli tylko o możliwości uniknięcia śmierci doczesnej. Pretensja zresztą śmiała, bo Chrystus, nawet jeśliby chciał skorzystać ze swej mocy cudotwórczej, to nie musiał przy tym salwować zarazem bandytę, $z$ tego tylko tytułu, że był współtowarzyszem jego cierpień.

Chrystus, jak na szyderstwa gawiedzi pod krzyżem, tak i na tę bezczelną kpinę, zareagował milczeniem. Zachowanie jednak złego łotra oburzyło drugiego współtowarzysza kaźni Chrystusowej. „Ani ty Boga się nie boisz - powiada - choć tę sama ponosisz karę. My co prawda sprawiedliwie, słuszna bowiem zapłate za uczynki odbieramy, ten wszakże nic złego nie uczynit!" Jest to wypowiedź pełna treści, która w kilkunastu słowach zawiera cały szereg momentów, ujawniających nieskażoną do głębi - mimo zbrodniczego życia - psychikę tego człowieka, „Ani ty Boga się nie boisz?" w tych słowach mieści się najpierw wyznanie wiary pod adresem Boga, Pana wszechświata i uznanie go za najwyższą świętość, którą - jeśli nawet wszystko inne runie - uszanować należy się bezwzględnie. Następnie przychodzi stwierdzenie, że cierpiąc tak jak ów współtowarzysz, powinien mieć dlań szacunek, a nie przyłączać się do jazgotu gawiedzi przeciwko niemu. Taką treść zdają się zawierać słowa: „Choć tee sama ponosisz karę." W całym tym zdaniu brzmi w każdym razie wyrzut, że złość szydercy przekracza już wszystkie granice, że go zaślepia, nie dając dojrzeć kim jest Ten, Kióry poddany jest równoczesnej każni. Następuje z kolei wyznanie włäsnej winy i przyjęcie cierpień i śmierci, jako należnej kary, zadośćczyniącej za popełnione przestępstwa: „My coprawda sprawiedliwie, słuszna bowiem zapłatę za uczynki odbieramy. A wreszcie przekonanie, że Chrystus cierpi niewinnie: „Ten, uszakże nic złego nie uczynit!"

Skąd u dobrego łotra ta postawa, tak odmienna od tej, jaka ujawnia jego aktualne otoczenie? Pismo św. powiada słusznie: „Bojaźn Boża poczatkiem mądrości!" $\left.{ }^{9}\right)$. W tej duszy - nieulękłej wobec niebezpieczeństw żywota łupieżczego - drzemała jednak najwidoczniej, wpojona zapewne w dzieciństwie, wiara w Boga, cześć dla niego i uznanie jego wszechwładnego autorytetu, a zatem i prawdziwa bojaźń boża, czyli obawa przed obrażeniem go grzechami. Wciągniety $\mathrm{w}$ wir życia zbrodniczego zaniedbał rozwinąc $\mathrm{w}$ sobie te dobre cechy, ale musiały one istotnie tkwić w duszy, kiedy doszły znowu

$\left.{ }^{9}\right)$ Przyp. 1, 7. 
do głosu w chwili, gdy wreszcie był najwyższy czas po temu, gdy zawisł między niebem a ziemią, gdy sprawy ziemskie zostały zamknięte aktem wyroku śmierci i gdy stanął wreszcie twarzą w twarz. z tą swoją pozagrobową przyszłością, której jedyną treścią - Bóg. sam. Cudowny zbieg okoliczności związał jego ostatnie chwile z ostatnimi chwilami Chrystusa. Była to wielka lekcja - jak należy cierpieć i umierać. Bez skargi - z modlitwą za oprawców na ustach. Trzeba było być do gruntu zaślepionym, by nie dojrzeć wzniosłości takiego zachowania się i nie czuć się zbudowanym. Dobry łotr sam. cierpiąc i konając $z$ bólu potrafił ocenić to tym bardziej, jakiej miary był jego współtowarzysz niedoli. Być może zresztą, że osoba Chrystusa nie była mu zupełnie obca. Kręcąc się wśród ludzi w celach rabunkowych mógł widzieć i słyszeć niejedno o Chrystusie. Jeśli tak było istotnie - to dotarła do niego też zapewne wiadomość o postawie Pana Jezusa wobec grzeszników. I to go ośmieliło do wystosowania swej prośby. Jeśli jednak tak nawet nie było, to napis. na krzyżu i bluźniercze otoczenie informowały go o tym, że Chrystus podawał się za Boga, Mesjasza i Króla. Co tamci kwestionowali on - patrząc na zachowanie Chrystusa - uznał za niewątpliwe i w jednej chwili staje się nie tylko wyznawcą, ale i apostołem, gdyż. stara się swą uwagą pociągnąc do dobra swego towarzysza. Uznając zaś słuszność ponoszonej kary daje dowód, że uznaje zło swych postępków. Spełnia więc dwa podstawowe warunki prawdziwego nawrócenia: wi erzy i żałuje - zaś wiara i żal — to początek zbawienia. Toteż $\mathrm{w}$ tych warunkach zaniesiona prośba zasługuje w pełni na wysłuchanie. Wyrażając ją słowami: „Panie, wspomnij na. mnie, gdy przybędziesz do królestwa twego!" - daje dowód zadziwiającej wiary, pokory i ufności.

Czegoż tu nie ma bowiem w tym krótkim zdaniu?! Uznanie Chrystusa królem i to $\mathrm{w}$ takiej chwili zewnętrznej przegranej! Wiara w jakieś życie pozagrobowe i w zmartwychwstanie - zarówno Chrystusa jak i własne - gdyż ten, Którego prosił o względy, stał. wraz z nim samym u progu śmierci, gdzieś zaś ich dusze musiałyby przebywać do chwili rezurekcji. Wiara w istnienie królestwa Chrystusowego, którego progi Jezus przekroczy w chwili śmierci. Wziąwszy, że ten, do którego zanosił tę prośbę, wisiał w chwili aktualnej nagi na krzyżu, otoczony wzgardą tłumu i starszyzny żydowskiej wiara w królewskość Chrystusa jest tak wstrząsająca w swym kontraście, że świadczy o prawdziwym zrozumieniu majestatu bożego, promieniującego nawet $\mathrm{z}$ tego ukrzyżowanego zewłoka ludzkiego. Być może, że wyobrażał on sobie to królestwo Chrystusowe nieco po ziemsku, wedle panującej wśród współczesnych Żydów opinii, ale musiała być tu i przymieszka życia zaświatowego, gdyż łotr nie prosi o salwowanie życia doczesnego, ale o zaliczenie w po- 
czet poddanych w królestwie pośmiertnym, a tym samym prosi i o darowanie win teraźniejszych, za które należała się w pojęciu każdego wierzącego Żyda kara nie tylko doczesna, ale i wieczna. Któż zaś grzechy darować może jeśli nie sam Bóg? Więc jest tu i wyznanie bóstwa Chrystusowego i jego mesjańskiej, odkupicielskiej misji.

Tak, piorunujące jest tu działanie łaski, bo nią tylko wytłumaczyć sobie można tak wielki plon, na tak malo obiecującym gruncie i w takim krótkim przeciągu czasu! Prawdziwe te słowa Izajasza: „Trzciny nadłamanej on nie dołamie, a lnianego, co dymi, knota nie dogasi!“" ${ }^{10}$ ). Iskierkę dobra, tlejącą w sercu dobrego łotra, Chrystus swą łaską rozniecił w płomień żalu doskonałego, który w jednej chwili oczyścil tę duszę ze zła i przysposobił do wiecznego szczęścia. "Choćby byty grzechy wasze, jako szkarłat, jako śnieg wybieleja i choćby byty czerwone, jako karmazyn, będa biate, jako wetna." "11)

Na słowa dobrego łotra, zwrócone pod jego adresem, odpowiedział Chrystus jednym, wymownym zdaniem: „Zaprawde powiadam tobie, dziś będziesz ze mna w raju!" W: obliczu śmierci nie ma długich dyskusji, więc i ta odpowiedź, choć krótka, zawiera wiele treści. Chrystus potwierdza przypisaną mu przez dobrego łotra godność królewską i daje iście królewską odpowiedź: wysłuchuje zaniesioną prośbe i to nie zwlekając, natychmiast, dziś jeszcze obiecuje jej spełnienie..Niezwykła postawa współtowarzysza kaźni, który sam jeden - złoczyńca! - ujął się za Chrystusem na krzyżu, poruszyła w sercu Jezusa żywą strunę wspaniałomyślności. Nie, Chrystusa nikt nie prześcignie w miłości i miłosierdziu. Oddaje miarą. dobrą i natiłoczoną! Spełnia zaś zarazem rolę sędziego, decyduje bowiem o dalszym losie skazańca, a żal jego nagradza całkowitym odpuszczeniem win. Prawdziwie to odpust zupełny w godzinie śmierci! Żydzi skupieni wokoło krzyża szyderczo domagali się cudu od Pana Jezusa, dla stwierdzenia swej boskości, królewskości i mesjaństwa. Chcieli cudu, który by olśnił ich oczy sensacyjnym efektem. Ślepcy zatwardziali nie dostrzegali rozgrywającego się równocześnie w ich obecności cudu zbawienia duszy, który więcej niż cokolwiek potwierdza te trzy zaprzeczane mu godności, do których Chrystus słusznie miał prawo.

Co jednak rozumieć należy ściśle pod terminem raju, jaki Chrystus obiecał dobremu łotrowi? W piśmie św. pojęcie raju pojawia się już na pierwszych jego stronach, gdy mowa o miejscu, w którym przebywali Adam i Ewa przed grzechem i z którego

10) Iz 42, 3,

11) Iz 1, 18. 
zostali wygnani. Pierwotnie Żydzi mniemali, że dusze dostają się do szeolu, pod którym pojmowali podziemne królestwo zmarłych. Panowała tam rzekomo ciemność, smutek i zapomnienie bez bólu. $Z$ czasem wytworzyło się przekonanie w zmartwychwstanie dusz i w odpłatę za życie na ziemi. Odróżniano już wówczas trzy miejsca, w których miały przebywać dusze. W jednym znajdować się miały dusze zbawionych, w drugim dusze potępionych, w trzecim dusze pokutujące - a więc coś w rodzaju naszego czyśca. Miejsce dla zbawionych $z$ czasem mianowano dwojakim terminem: raj i niebo. Raj: Gan Eden czyli Ogród Eden, ogród rozkoszy, ogród królewski, ogród życia. Rozróżniano dwa raje. Jeden tymczasowy w niebie, drugi po zmartwychwstaniu, między niebem a ziemią lub na krańcach ziemi na miejscu raju Adama i Ewy. Pojmuje się go jako nagrodę za dobre życie w formie współżycia z Bogiem. Nie utożsamiano go $z$ szeolem, który $z$ czasem nabrał ujemnego znaczenia.

Takie wierzenia panowały wśród Żydów za czasów Chrystusa Pana. Sw. Paweł powiada: ,Znam człowieka $w$ Chrystusic - a miał tu na myśli samego siebie - który przed 14 laty (czy w cicle nie wiem czy poza ciałem nie wiem, Bogu do wiadomo) zachwycony byt do trzeciego nieba. I wiem, że ten człowiek (czy w ciele czy poza ciatem nie wiem, Bóg to wie) zachwycony byt do raju i posiyszał tajemnicze stowa, których człowiekowi mówić sie nie $\left.\operatorname{god} z i^{\prime \prime}{ }^{12}\right)$.

Chrystus obiecując dobremu łotrowi raj, wyraża się popularnie, używając terminu współczesnego, pod którym rozumiano miejsce, do którego idą zmarli, którym należy się nagroda za życie cnotliwe. Tak też rozumiał to powiedzenie św. Eukasz, utożsamiając raj ze szczęściem życia pozagrobowego. W rzeczywistości dusza Chrystusa oraz łotra dobrego poszły po śmierci do otchłani, gdzie przebywały dusze sprawiedliwych, oczekujące na swe zbawienie wieczne. O tym to miejscu św. Piotr mówi: „W duchu nawet do tych duchów, k.tóre przebywały w więzieniu, udał sie (Chrystus) przepowiadać" ${ }^{13}$ ). Niebo, rozumiane w naszym pojęciu, jeszcze wówczas nie istniało, gdyz otwarte zostało dla zbawionych dopiero po zmartwychwstaniu, a ściślej mówiąc po wniebowstąpieniu Pana Jezusa. Zarówno otchłań, jak i niebo w gruncie rzeczy nie implikują konieczności istnienia miejsca $\mathrm{w}$ materjalnym znaczeniu tego słowa, gdyż dusze, jako substancje niematerialne, miejsca nie zajmują. Jednak teologowie katoliccy pojmują niebo także w znaczeniu miejsca, zwłaszcza że po zmartwychwstaniu dusze połączą się ze swymi ciałami.

12) 2 Kor. 12, $2-4$.

13) 1 Piotr 3, 19. 
Obietnica swą przyznaje Chrystus dobremu łotrowi w jednej chwili to na co dusze sprawiedliwych czekały od wieków. Jest on niejako pierwszym zbawionym, jakby namacalnym dowodem skuteczności ofiary krzyżowej. A że łaski tej dostąpił sam także w godzinę śmierci słusznie nazywa go Daniel Rops - nawiązując do jednej z przypowieści Chrystusowej - pracownikiem jedynastej godziny, który dostał najwyższą zapłatę, choć ostatni stanął do pracy! Laska ostatniej godziny jest istotnie łaską zadziwiającą. Ekonomia Boża ma ją jak gdyby w specjalnej rezerwie i stosuje w wyjątkowych wypadkach, ratując nią zaś dusze od zagłady daje dowód, że i taką wartość rzucić potrafi na szalę, gdy chodzi o to, by grzesznik nie zginą - ale żył!

A ten, który zyskał sobie w tradycji kościelnej miano złego łotra czy i on nie został obdarzony, bardziej niż na to zasłużył, laską nawrócenia? Ewangelia o tym milczy, ale może upomniany przez swojego towarzysza i słysząc obietnicę daną mu przez Chrystusa zdołał się zdobyć choć na żal niedoskonały - z chęci nagrody - i tym uchronił się od potępienia? Oba te fakty były dlań niewątpliwie tym, co Kościół nazywa łaskami zewnętrznymi (dobre pouczenie, godziwy przykład). Od chwili jego bluźnierstwa aż do momentu zgonu upłynęło wszakże około dwóch godzin! Tak bardzo chciałoby się wierzyć, że krew Chrystusowa, obu towarzyszy męki obmyła z grzechów. Co prawda Ojcowie Kościoła powiadają, że Chrystus tylko jednego grzesznika nawrócił w ostatniej godzinie, by grzesznicy mieli przykład i nie wątpili o możliwości otrzymania łaski przebaczenia w chwili śmierci, ale tylko jednego, by nie pobudzać ich do lekkomyślnego odkładania poprawy aż do ostatniej chwili $\left.{ }^{14}\right)$. Mogło to być tylko jedno nawrócenie jawne, potwierdzone przez świadectwo ewangelii, a drugie rozegrać się mogło w giębi serca i ta wypowiedź Ojców Kościoła chyba nie kładzie tamy nadziei, że śmierci zbawicielskiej Chrystusa nie towarzyszyło równoczesne potępienie drugiego skazańca!

Jeśli zaś chodzi o dobrego łotra - to pamięć jego czezona jest na wielu miejscach. Istotnie uchodzić on może za patrona dobrej śmierci.

\section{ROZMYSLANIE}

Stań w myśli pod krzyżem Chrystusowym I przeżyj scenę, jaka się tam rozegrała. Z bólem serca rozważ zaślepienie Żydów, którzy swym złym przykładem pobudzili do bluźnierstw złego

14) Ks. Władysław Szczepański: Bóg-Człowiek w opisie ewangelistów, Kraków 1936, s. 392, nota 2. 
łotra. Podziwiaj wiarę i skruchę dobrego łotra i jego prośbę o łaskę zbawienia. Uczcij wielkoduszność i miłosierdzie Chrystusa, obiecującego dobremu łotrowi miejsce w raju. Podziękuj za udzielona. mu łaskę nawrócenia w chwili śmierci. Proś by tej łaski udzielił Bóg wielu, wielu grzesznikom.

\section{ZASTOSOWANIE}

\section{Ogólne}

Czy znane nam są przykłady ludzi ociągających się ze swym nawróceniem aż do chwili śmierci? Jakie bywaja przyczyny takiego zachowania się. Czy rodziny umierających dbają dostatecznie o zapewnienie ciężko chorym obecności kapłana w takiej chwili? Czy lęk przed przyśpieszeniem śmierci nie wstrzymuje ich przed ujawnieniem istniejącego niebezpieczeństwa fizycznego i moralnego? Czy znane są nam wypadki uzyskania łaski ostatniej godziny przez zatwardziałych grzeszników? Jakie wywieraja one wpływ na otoczenie? Czy znamy wypadki odzyskania zdrowia po udzieleniu ostatnich sakramentów?

\section{Osobiste}

Czy zastanawiam się czasami nad chwilą mej przyszłej, własnej śmierci? Czy staram się dobrym życiem zapewnić sobie dobrą śmierć? Czy nie ponoszę odpowiedzialności za niezaopatrzenie przedśmiertne sakramentami wś. kogoś z bliskich mi zmarłych? Czy modlę się do miłosiernego Chrystusa c łaskę nawrócenia zá zatwardziałych grzeszników, a zwłaszcza o łaske ostatniej dla nick godziny?

\section{POSTANOWIENIA ZBIOROWE I INDYWIDUALNE}

Szerzenie przekonania o ważności dobrego przygotowania na śmierć. Modlitwa za zatwardziałych grzeszników. Rozważania o śmierci. Pogłębianie w sobie i innych przekonania o większym znaczeniu losu wiecznego od doczesnego. Modlitwa o dobrą śmierć.

\section{vI. MODLITWA}

Uczczenie Chrystusa miłosiernego, obiecującego dobremu łotrowi raj. Wynagrodzenie Panu Jezusowi za doznane na krzyżu bluźnierstwa. Za zatwardziałych grzeszników. O dobrą śmierć dla siebie i najbliższych. O odwagę dla umierających i dla osób, które sa przy cudzej śmierci obecne, w wypełnieniu obowiązków moralnych, związanych z tą chwila. 